\title{
Article \\ Effects of Different Crop Root Systems on Soil Detachment by Concentrated Flow on the Loess Plateau in China
}

\author{
Jiaqian Sun ${ }^{1}$, Pei Lu ${ }^{2, *}$, Yongxiang Cao ${ }^{1,3}$, Naichang Zhang ${ }^{1}$, Faqi Wu ${ }^{4}$ and Peng Li ${ }^{5}$ \\ 1 Powerchina Northwest Engineering Corporation Limited, Xi'an 710065, China; \\ sunjiaqian1990@sina.com (J.S.); cyx00032@163.com (Y.C.); xkznc@163.com (N.Z.) \\ 2 Shaanxi Key Laboratory of Ecological Restoration in Shanbei Mining Area, College of Life Science, \\ Yulin University, Yulin 719000, China \\ 3 Shaanxi Provincial River and Lake Ecological Protection and Restoration Engineering Technology Research \\ Center, Xi'an 710065, China \\ 4 College of Natural Resources and Environment, Northwest A\&F University, Xianyang 712100, China; \\ wufaqi@263.net \\ 5 State Key Laboratory of Eco-Hydraulics in Northwest Arid Region of China, Xi'an University of Technology, \\ Xi'an 710048, China; lipeng74@163.com \\ * Correspondence: lupei728@163.com
}

check for updates

Citation: Sun, J.; Lu, P.; Cao, Y.; Zhang, N.; Wu, F.; Li, P. Effects of Different Crop Root Systems on Soil Detachment by Concentrated Flow on the Loess Plateau in China. Water 2022, 14, 772. https://doi.org/ $10.3390 /$ w14050772

Academic Editor: Xudong Peng

Received: 29 January 2022

Accepted: 23 February 2022

Published: 28 February 2022

Publisher's Note: MDPI stays neutral with regard to jurisdictional claims in published maps and institutional affiliations.

Copyright: (C) 2022 by the authors. Licensee MDPI, Basel, Switzerland. This article is an open access article distributed under the terms and conditions of the Creative Commons Attribution (CC BY) license (https:// creativecommons.org/licenses/by/ $4.0 /)$.

\begin{abstract}
Soil erosion in sloping cropland is a major water and soil conservation issue in the Loess Plateau region, one of the main areas with sloping cropland in China. However, the effect of crop root systems, a major factor potentially influencing soil and water conservation in cropland, on farmland erosion, remains unclear. In the present study, soil erosion was investigated using indoor runoff scouring experiments with millet, maize, and soybean cover, with a bare surface as the control (CK), on sloping surfaces. Crop root system characteristics, rill initiation time, and erosion law, as well as their interactions, were investigated. Rill initiation time in slopes with all three crops slope were greater than that in the bare slope, indicating that crops could significantly enhance soil anti-scourability. Soil detachment rate decreased under crop cover when compared with bare land, considering the average soil detachment rate was the highest under $\mathrm{CK}$, followed by under maize and soybean, and the least under millet. Slope gradient and unit discharge rate were positively correlated with soil detachment rate. Root length density, root surface area density, and root volume density were negatively correlated with soil detachment rate. Moreover, roots in the $0-1 \mathrm{~mm}$ diameter range dominantly influenced soil erosion.
\end{abstract}

Keywords: soil detachment rate; sloping cropland; crop; root characteristics

\section{Introduction}

Agricultural management practices during perennial cultivation are sources of disturbance in cropland soils and result in loose topsoil structure and unstable vegetation cover. Similarly, soil erosion is more widespread in croplands than under natural forest and grassland ecosystems [1,2]. More than 33\% of global cropland is affected by soil erosion, whereas the proportion affected in China is as high as $40 \%$ according to the national planning of soil-water conservation for slope farmland in 2009 from the Ministry of Water Resources of the People's Republic of China (MWR). The Loess Plateau is one of the most severely eroded and fragile ecosystems globally, particularly on sloping cropland [3,4]. On the Loess Plateau, the area of cropland with a slope $>3^{\circ}$ accounts for $47.7 \%$ of the total cultivated area, with soil erosion in cropland accounting for 50-60\% of the total erosion [5]. Severe soil erosion on sloping cropland would not only lead to decline in soil fertility and crop yield, but also cause sediment deposition and non-point source pollution in rivers, lakes, and reservoirs, which are major threats to agricultural development in the plateau region [6-9]. 
Vegetation communities play an important role in the prevention and control of soil erosion in most climatic zones [10]. Numerous studies have demonstrated that restoration of vegetation could reduce soil detachment and transport significantly [11-13]. From a hydrological perspective, the anti-erosive mechanisms of vegetation include two major pathways. Firstly, vegetation canopy can intercept raindrops, thereby minimizing their splashing effect on the soil surface, in addition to delaying runoff initiation time [14,15]. Secondly, the root systems of vegetation can enhance soil stability and water dispersion resistance by increasing the number and diameter of soil water-stable aggregates [16-18]. Furthermore, vegetation litter in woodlands reduces runoff and sediment losses by decreasing splash erosion and increasing soil roughness, and the minimization of runoff speed and scale increases soil infiltration [19-21].

In comparison to common forest and grass vegetation, crops are unique annual herbaceous plants that typically exhibit single species composition, simple vegetation structure, and significantly seasonal succession [22,23]. Notably, soil erosion studies have mainly focused on woodland and grassland ecosystems, with studies on the effects of crop cover on farmland erosion being relatively limited [24-26]. Consequently, further studies on the role and contribution of crop cover to runoff regulation and soil erosion mitigation, particularly in farmland, should be carried out $[27,28]$.

Some researchers have reported that crop cover decreases soil erosion. Ma et al. [29] observed runoff and sediment loss dynamics at different maize growth stages and reported that the average runoff amount and sediment yield in maize fields were $23.80 \%$ and $44.25 \%$ lower, respectively, than those in bare soil. Similarly, Zhao et al. [30] studied soil detachment under spring wheat throughout its growth period and reported that the soil loss on croplands with spring wheat was $90 \%$ lower in all growth stages than in bare cropland. Furthermore, crop species and planting density influence soil erosion on farmland. Carroll et al. [31] reported lower runoff and soil loss in wheat fields than in sorghum and sunflower fields in Australia. In addition, Basic et al. [32,33] reported higher rates of soil erosion in low-density spring crops than in high-density winter crops under similar tillage conditions. Although all the factors above influence the physical characteristics of both plant canopy and root system, many studies have demonstrated that roots play a more prominent role in reducing soil erosion than the canopy $[34,35]$. Therefore, investigation of the effect of root system on soil erosion could reveal soil erosion mechanisms under flow scouring.

Despite a growing number of studies investigating the effect of crop cover on soil erosion, most of such studies have considered the effect of vegetation as a whole, while seldom examining the role of root systems in the process and the underlying mechanisms. Consequently, the objective of the present study was to assess the effects of crop root systems in regulating runoff and soil loss under different crop species and planting densities, across different slope gradient and discharge gradients. The results of the present study could reveal the mechanisms via which crop root systems reduce erosion.

\section{Materials and Methods}

\subsection{Experiment Setup and Materials}

The experiments were carried out at the Soil and Water Conservation Engineering Laboratory, Northwest A\&F University, Shaanxi Province, China. A rectangular flume ( $6.0 \mathrm{~m}$ long, $1.0 \mathrm{~m}$ wide, and $0.3 \mathrm{~m}$ deep) was used in the experiments in the present study. The flume was divided into two parts in the longitudinal direction by a glass wall located at the flume's centerline, so that two replicate experiments could be run simultaneously. The flume walls and bed were made of toughened glass fixed with metal rods. A hydraulic jack located under the flume allowed for the adjustment of the slope gradient $\left(0-15^{\circ}\right)$. The lower $0.05 \mathrm{~m}$ of the flume was filled with natural fine gravel $(2-4 \mathrm{~mm})$, and a $0.2 \mathrm{~m}$ thick layer of soil was placed on top of the gravel (Figure 1). 


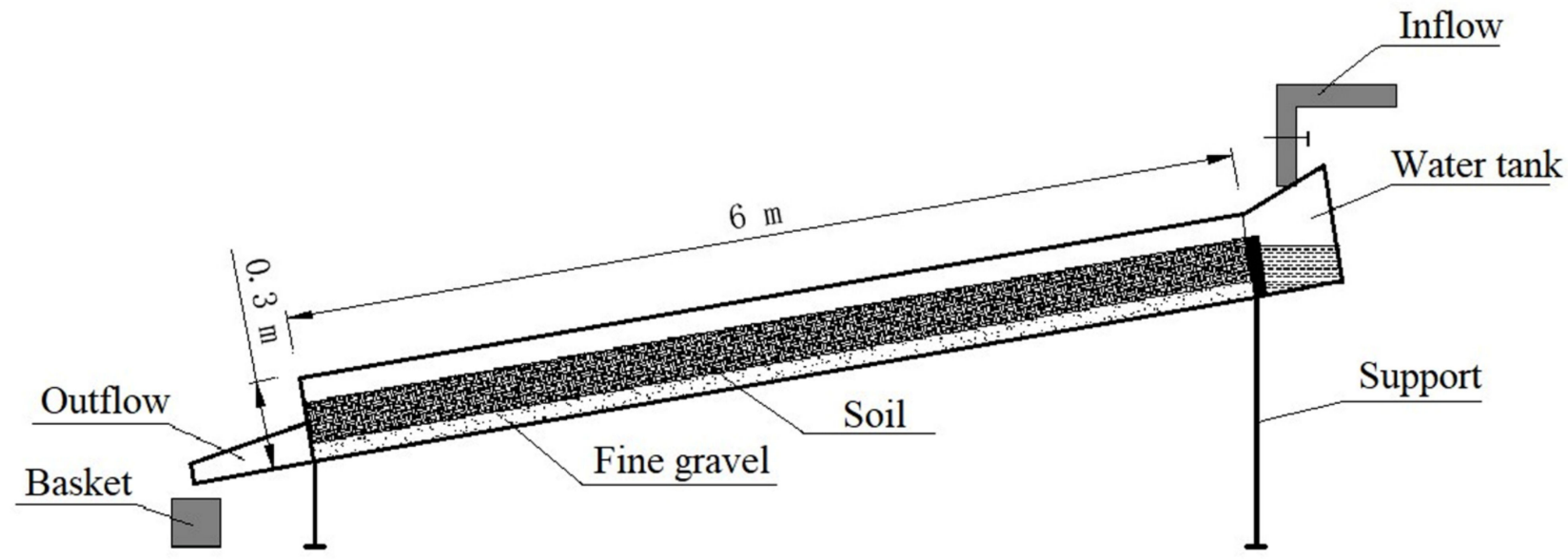

Figure 1. Sketch of the set up for the flume experiment.

The experimental soil was collected from the plough layer $(0-30 \mathrm{~cm})$ of a fallow cropland in Yangling District, Xianyang City, Shaanxi Province, China, which is located in the middle of Guanzhong Plains on the south edge of the Loess Plateau. The tested soil is classified as Lou soil in the Chinese Soil Classification System. It is a common soil type in the Guanzhong plain area in Shaanxi Province, China, and an excellent agricultural soil formed following long-term cultivation of the so-called Cinnamon Soil. The soil has a gray-brown color (10YR5/2) and a granular structure. It is classified as an Anthrosol in the WRB (World Reference Base) for Soil Resources. Some intrinsic properties of the experimental soil are listed in Tables 1 and 2. All the tested soils were air-dried and sieved $(0.01 \mathrm{~m})$ before being used to fill the flume, in order to ensure homogeneity. When the flume was being filled, the soil was gently tapped to achieve a near-uniform bulk density of around $1.35 \mathrm{~g} / \mathrm{cm}^{3}$ and then left to sit outdoors for six months in order to ensure the test soil had characteristics similar to those of natural cropland soil in the Loess Plateau region [36,37].

Table 1. The chemical composition of the tested soil.

\begin{tabular}{cccccc}
\hline Chemical Composition & Organic Matter & Total Nitrogen & Alkaline Nitrogen & Total Phosphorus & Total Potassium \\
\hline Content $\left(\mathrm{g} \cdot \mathrm{kg}^{-1}\right)$ & $5.0-15.0$ & $0.5-1.3$ & $0.023-0.08$ & $0.002-0.023$ & $17.1-40.8$ \\
\hline
\end{tabular}

Table 2. The particle size distribution of the tested soil.

\begin{tabular}{ccccccc}
\hline Particle Size $(\boldsymbol{\mu m})$ & $\mathbf{1 0 , 0 0 0 - 2 5 0 0}$ & $\mathbf{2 5 0 0 - 5 0 0}$ & $\mathbf{5 0 0 - 1 0 0}$ & $\mathbf{1 0 0 - 5 0}$ & $\mathbf{5 0 - 1 0}$ & $<\mathbf{1 0}$ \\
\hline Percentage $(\%)$ & 0.4 & 8.6 & 44.2 & 13.5 & 21.7 & 11.6 \\
\hline
\end{tabular}

Notes: D50 = $1.17 \times 10^{2} \mu \mathrm{m} ; \mathrm{D} 84=3.68 \times 10^{2} \mu \mathrm{m} ; \mathrm{D} 90=4.67 \times 10^{2} \mu \mathrm{m}$.

Three crops were tested in the experiments, namely, millet (Setaria italica. cv. "Jingu29"), maize (Zea mays L. cv. "Zhengdan 958"), and soybean (Glycine max (Linn.) Merr. cv. "Zhonghuang 13"), which are the dominant crops on arable land in the Loess Plateau. The crops were planted in the experimental flume after cultivation. To ensure consistency with normal planting density, we drilled millet, maize, and soybean seeds into soil with row spacings of $0.2 \mathrm{~m}, 0.6 \mathrm{~m}$, and $0.4 \mathrm{~m}$, respectively, and plant spacings of $0.1 \mathrm{~m}, 0.25 \mathrm{~m}$, and $0.2 \mathrm{~m}$, respectively (Figure 2). Moreover, a no-tillage treatment, a macroscopic bare soil surface without any vegetation cover, was set up as a control (CK) to investigate how the root systems of different crops influence soil detachment. 

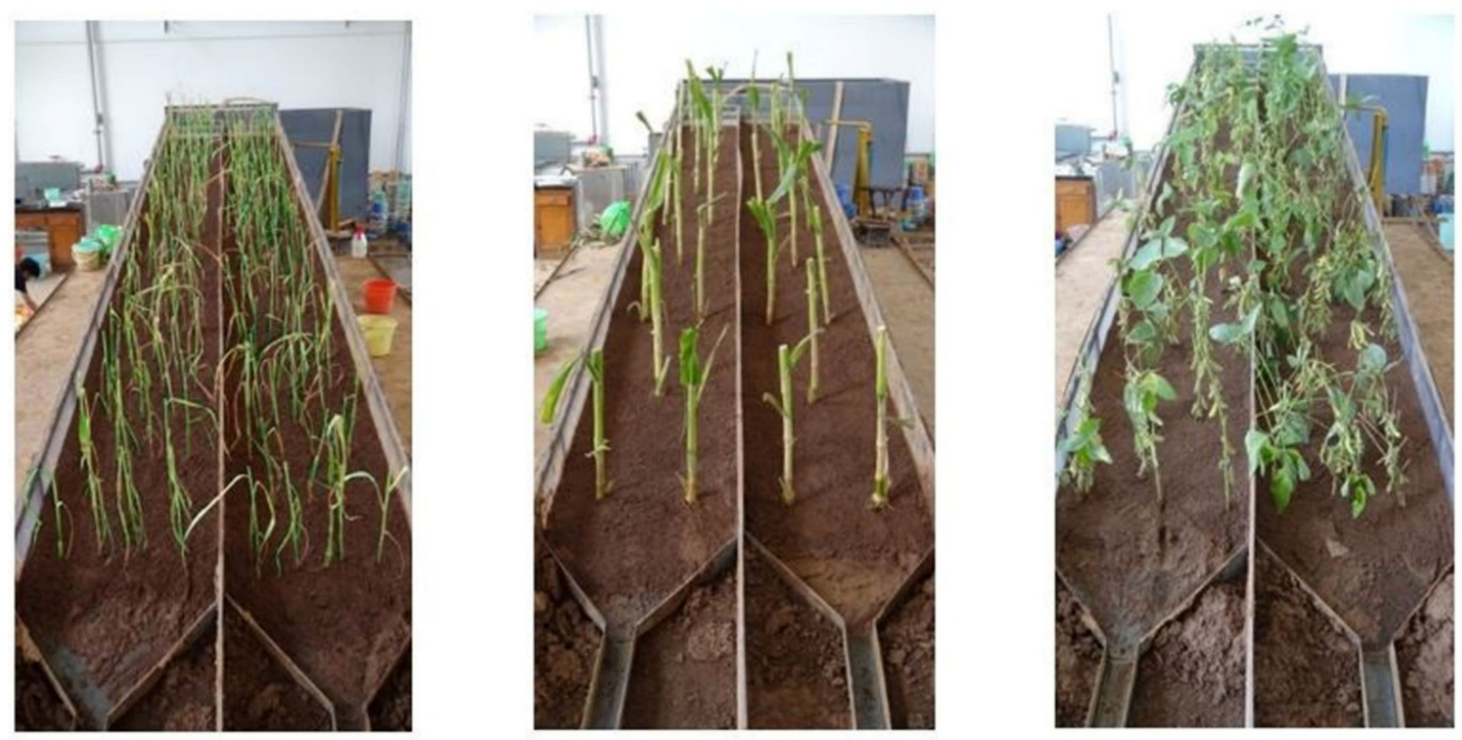

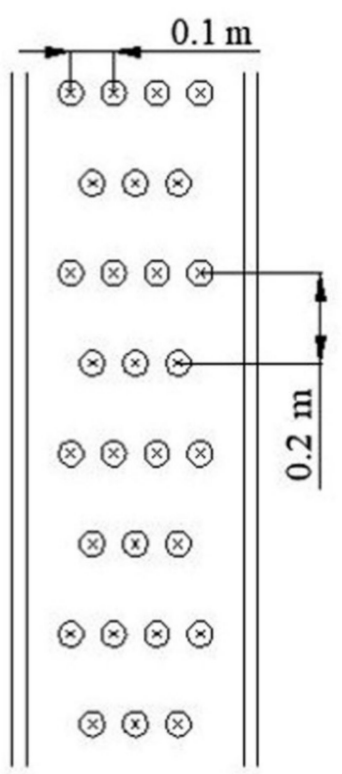

(a)

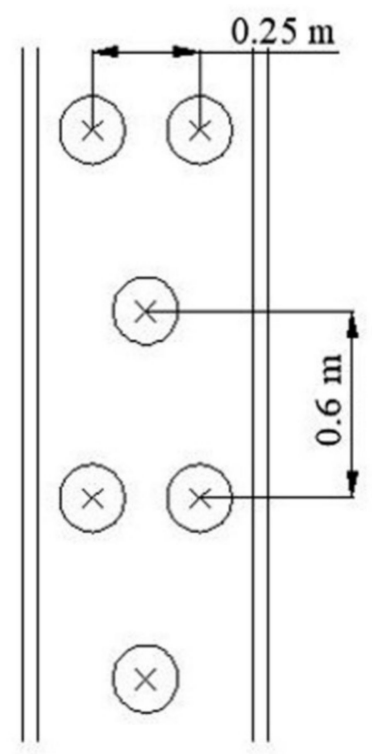

(b)

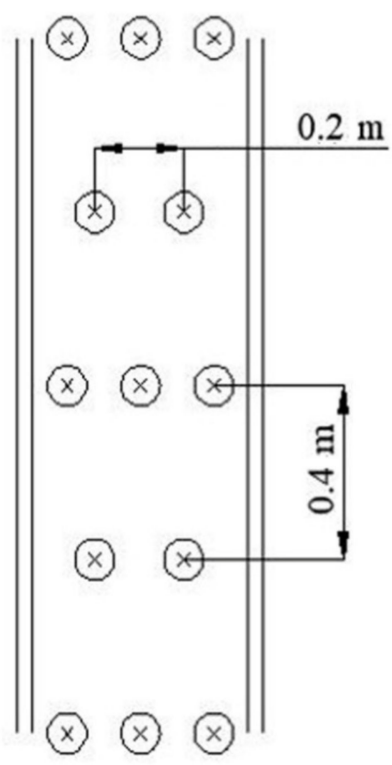

(c)

Figure 2. The layouts of the crops: (a) Millet; (b) Maize; (c) Soybean.

To study the effect of crop root system on farmland erosion by concentrated flow, we applied the runoff scouring method in the present study to directly investigate the soil reinforcement effects of crop root systems, and in turn the effects on soil anti-scourability and anti-erodibility. Experiments were carried out under five unit discharge rates $(0.10$, $0.15,0.20,0.25$, and $\left.0.30 \mathrm{~L} \mathrm{~m}^{-1} \mathrm{~s}^{-1}\right)$, which were equivalent to different rainfall intensities $(60,90,120,150$, and $180 \mathrm{~mm} / \mathrm{h}$, respectively) in the effective rainfall area of the flume $(6 \mathrm{~m}$ $\times 0.5 \mathrm{~m}$ ). The rainfall intensity ranges are based on long-term monitoring in the Loess Plateau region $[38,39]$. Unit discharge rate was defined using the following equation:

$$
q=\frac{Q}{b}
$$

where $q$ is unit discharge rate $\left(\mathrm{L} \mathrm{m}^{-1} \mathrm{~s}^{-1}\right), Q$ is the discharge rate $\left(\mathrm{L} \mathrm{s}^{-1}\right)$, and $b$ is the width of the flume $(\mathrm{m})$. Different slopes $\left(2^{\circ}, 4^{\circ}, 6^{\circ}, 8^{\circ}, 10^{\circ}\right.$, and $\left.12^{\circ}\right)$ were set up in the 
experiments. Before each experiment, the flume was set at the desired slope gradient. At the start of an experiment, the water supply system was turned on to apply a preset discharge at the upper flume end. Incoming discharge was controlled by a flowmeter. The flowmeter was calibrated before each experiment to ensure the real discharge was consistent with the design discharge. Each experiment lasted $20 \mathrm{~min}$, during which hydraulic measurements were obtained. At the bottom end of the flume, samples were collected for use in measurement of outgoing discharge and soil losses.

\subsection{The Measurement and Calculation of the Root Parameters}

The millet, maize, and soybean plants that were tested in the experiment were all $60 \mathrm{~d}$ after seedling emergence to minimize the influence of planting time. After the experiment, all tested crops were taken out from the slope with soil attached, in order to avoid damaging the roots, and the roots were analyzed. Subsequently, the stems and leaves of the crops were cut off and only the roots were retained, which were washed repeatedly with clean water until there was no residual soil attached. Root parameters, including root diameter (D), root length (RL), root surface area (RSA), and root volume (RV), were measured using a WinRhizo root analysis software (Regent, Canada), which is capable of applying both Regent's non-statistical method (WinRHIZO method) and Tennant's statistical method (line-intersect method) [40]. In addition, the system can detect and make corrections for areas of root overlap to ensure accurate results (Figure 3).

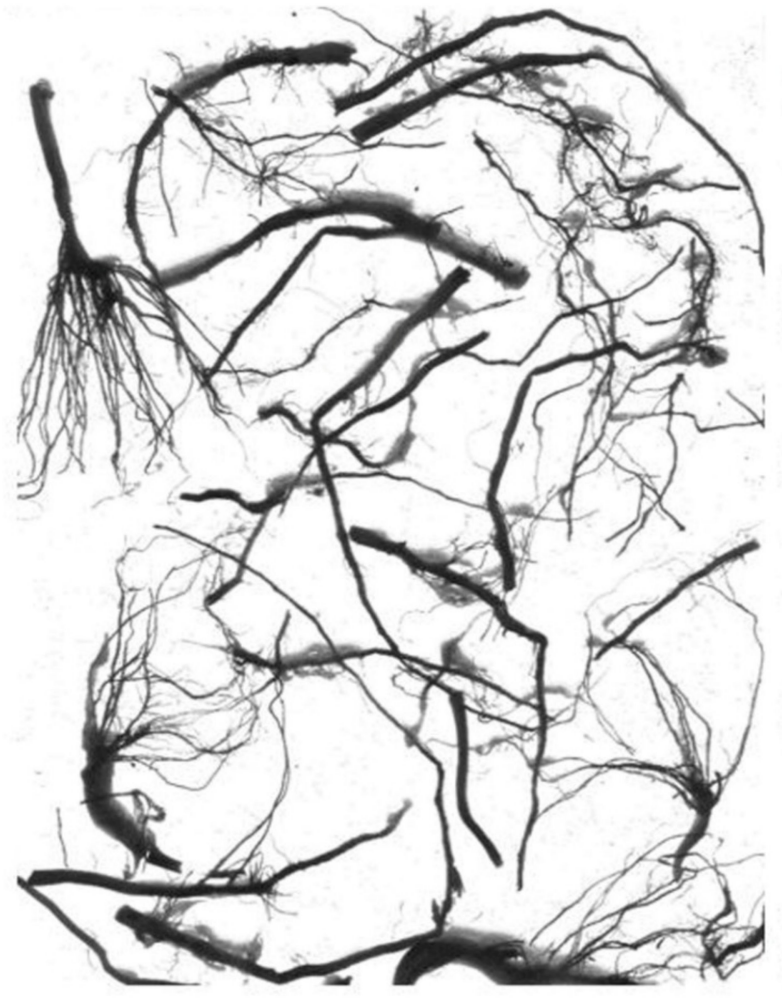

(a)

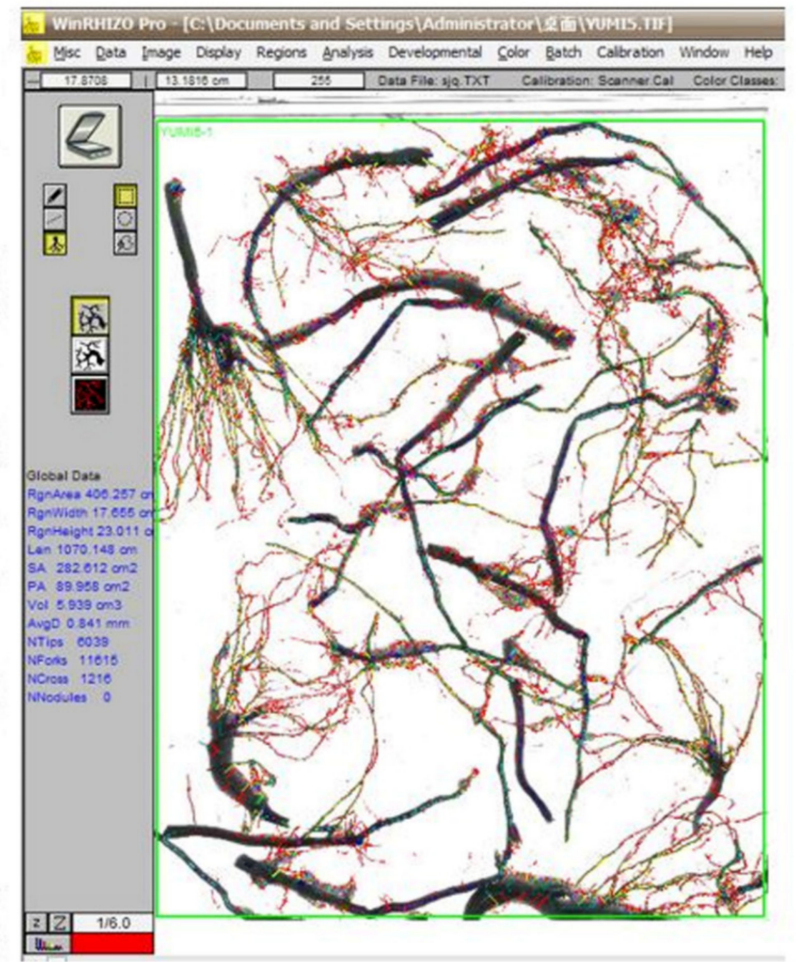

(b)

Figure 3. The root scanning system: (a) Root samples; (b) Scanning result.

Considering the different planting density of crops, we estimated the root parameters as follows:

$$
\begin{aligned}
R L D & =\frac{R L \cdot N}{V} \\
R S A D & =\frac{R S A \cdot N}{V}
\end{aligned}
$$




$$
R V D=\frac{R V \cdot N}{V}
$$

where $R L D$ is root length density $\left(\mathrm{m} \mathrm{m}^{-3}\right), R L$ is root length $(\mathrm{m}), R S A D$ is root surface area density $\left(\mathrm{m}^{2} \mathrm{~m}^{-3}\right), R S A$ is root surface area $\left(\mathrm{m}^{2}\right), R V D$ is root volume density $\left(\mathrm{m}^{3} \mathrm{~m}^{-3}\right)$, $R V$ is root volume $\left(\mathrm{m}^{3}\right), N$ is number of crop plants, and $V$ is volume of the soil in the flume $\left(\mathrm{m}^{3}\right)$.

After scanning, the tested root samples were oven-dried at $80{ }^{\circ} \mathrm{C}$ for $72 \mathrm{~h}$. Afterward, each sample was weighed using an electronic precision balance. The root weight density was calculated using the following equation:

$$
R D=\frac{R W \cdot N}{V}
$$

where $R D$ is root weight density $\left(\mathrm{kg} \mathrm{m}^{-3}\right)$ and $R W$ is root dry weight $(\mathrm{kg})$.

The volumes of runoff and sediment samples collected at the bottom end of the flume were first measured using a standard cylinder. Afterward, they were allowed to settle for $24 \mathrm{~h}$ and were oven-dried at $105^{\circ} \mathrm{C}$ for $12 \mathrm{~h}$, and then the samples were weighed. The soil detachment rate was calculated using the following equation:

$$
D r=\frac{W}{A \cdot t}
$$

where $D r$ is the soil detachment rate $\left(\mathrm{g} \mathrm{m}^{-2} \mathrm{~s}^{-1}\right), W$ is the weight of soil loss $(\mathrm{g}), t$ is the duration of the experiment (s), and $A$ is the wetted surface area of flume $\left(\mathrm{m}^{2}\right)$.

\subsection{Statistical Analysis}

Data were analyzed using IBM SPSS Statistics 19 (IBM Corp., Armonk, NY, USA). Analysis of variance (ANOVA) and Fisher's least significant difference (LSD) tests were used to compare soil detachment rates among different crops. The effects of RD, RLD, RSAD, and RVD on soil detachment rate were analyzed using one-way ANOVA. All the results are reported at the $\alpha=0.05$ level of significance. Regression analysis was used to establish relationships between soil detachment rates and hydraulic variables.

\section{Results and Discussion}

\subsection{Rill Initiation Time with Different Crops Cover}

The rill initiation time on tested slopes with millet, maize, and soybean are shown in Table 3. Rill initiation times in the slopes of all three crops were greater than that on the smooth slope, in the order of millet $(4.91 \mathrm{~min})>$ soybean $(4.11 \mathrm{~min})>$ maize $(3.35 \mathrm{~min})>$ CK (2.67 min), which indicated that crops could significantly increase the time required to produce rills on sloping farmland, i.e., crops enhanced soil anti-scourability compared to the bare land. Notably, millet crop had the most enhanced soil anti-scourability, followed by soybean crop, with the least enhancement under maize crop.

Root systems did not always play a dominant role in the erosion process, as we observed overland flow in the early stages of the experiments when rills had not yet been formed. Therefore, we recorded runoff initiation time under different crop covers at the bottom end of the flume. According to the data, runoff initiation time was in the order of millet $(3.99 \mathrm{~min})>$ maize $(2.98 \mathrm{~min})>$ soybean $(2.36 \mathrm{~min})>\mathrm{CK}(1.67 \mathrm{~min})$. The results indicate that crops could delay runoff initiation time, which is consistent with the findings of previous studies [39]. 
Table 3. The summarization of rill initiation time with different crops.

\begin{tabular}{|c|c|c|c|c|c|}
\hline \multirow{2}{*}{ Unit Discharge $\left(\mathrm{L} \mathrm{m}^{-1} \mathrm{~s}^{-1}\right)$} & \multirow{2}{*}{ Slope Gradient $\left(^{\circ}\right)$} & \multicolumn{4}{|c|}{ Rill Initiation Time (Min) } \\
\hline & & CK & Millet & Maize & Soybean \\
\hline \multirow{6}{*}{0.1} & 2 & 5.32 & 10.47 & 6.31 & 7.24 \\
\hline & 4 & 5.14 & 9.54 & 6.09 & 7.34 \\
\hline & 6 & 4.29 & 8.16 & 5.31 & 6.13 \\
\hline & 8 & 4.13 & 7.02 & 4.69 & 5.77 \\
\hline & 10 & 3.38 & 5.83 & 3.85 & 5.20 \\
\hline & 12 & 2.31 & 4.64 & 3.20 & 4.06 \\
\hline \multirow{6}{*}{0.15} & 2 & 4.55 & 7.54 & 5.69 & 6.55 \\
\hline & 4 & 4.17 & 6.86 & 5.26 & 6.18 \\
\hline & 6 & 3.25 & 6.49 & 4.81 & 5.73 \\
\hline & 8 & 2.86 & 5.59 & 4.04 & 4.92 \\
\hline & 10 & 2.51 & 4.33 & 3.82 & 4.15 \\
\hline & 12 & 1.73 & 3.61 & 2.55 & 3.33 \\
\hline \multirow{6}{*}{0.2} & 2 & 3.88 & 6.21 & 4.60 & 5.77 \\
\hline & 4 & 3.34 & 5.73 & 4.06 & 5.22 \\
\hline & 6 & 3.02 & 5.15 & 3.52 & 4.46 \\
\hline & 8 & 2.41 & 4.59 & 3.24 & 3.80 \\
\hline & 10 & 2.10 & 3.60 & 2.63 & 3.29 \\
\hline & 12 & 1.57 & 3.08 & 1.81 & 2.84 \\
\hline \multirow{6}{*}{0.25} & 2 & 2.96 & 5.32 & 3.39 & 4.53 \\
\hline & 4 & 2.23 & 4.46 & 2.76 & 3.64 \\
\hline & 6 & 1.78 & 3.77 & 2.33 & 2.99 \\
\hline & 8 & 1.44 & 3.26 & 2.08 & 2.52 \\
\hline & 10 & 1.19 & 2.81 & 1.95 & 2.17 \\
\hline & 12 & 0.98 & 2.54 & 1.60 & 1.94 \\
\hline \multirow{6}{*}{0.3} & 2 & 2.52 & 4.43 & 2.91 & 3.46 \\
\hline & 4 & 1.96 & 3.49 & 2.24 & 2.70 \\
\hline & 6 & 1.57 & 2.70 & 1.83 & 2.22 \\
\hline & 8 & 1.33 & 2.31 & 1.60 & 1.91 \\
\hline & 10 & 1.23 & 1.98 & 1.39 & 1.56 \\
\hline & 12 & 0.94 & 1.77 & 1.06 & 1.42 \\
\hline
\end{tabular}

In addition, runoff initiation time in all slopes under the three crops were longer than the corresponding rill initiation times, which demonstrated that runoff initiation time was mainly influenced by the resistance effect of the slope surface on runoff, with no direct relationship with crop roots within the soil. Table 4 lists aboveground plant part characteristics of different crops, including plant number, planting density, and average ground diameter. Considering the fact that stem cross-sections are generally circular, we found that the proportions of the cross-sectional areas of the different crop stems in the total slope area were in the following order: millet $>$ maize $>$ soybean, which is consistent with the order of runoff initiation time. In the case of overland flow, the larger the cross-sectional area of crop stems accounting for the slope area, the stronger the flow resistance effect of crops on the flow.

Table 4. The parameters of aboveground part of different crops.

\begin{tabular}{cccc}
\hline Land Surface Parameter & Millet & Maize & Soybean \\
\hline Number of plants & 95 & 11 & 33 \\
Plant density (quantity $\left./ \mathrm{m}^{2}\right)$ & 31.7 & 3.7 & 11.0 \\
Average ground diameter $(\mathrm{mm})$ & $9.3 \pm 2.7$ & $25.6 \pm 5.4$ & $14.3 \pm 3.2$ \\
\hline
\end{tabular}

Note: As an example, $9.3 \pm 2.7$ refers to the mean with standard deviations; the same is the case in other cells.

Figure 4 shows that rill initiation time in cropland with millet, maize, and soybean on $2^{\circ}$ slopes were $10.47,6.33$, and $7.24 \mathrm{~min}$, respectively, under a unit discharge rate of $0.1 \mathrm{~L}$ 
$\mathrm{m}^{-1} \mathrm{~s}^{-1}$. When the slope gradient increased to $12^{\circ}$, rill initiation times in millet, maize, and soybean crops decreased to $4.64,3.20$, and $4.06 \mathrm{~min}$, respectively. Such trends were also observed under other unit discharge rates, indicating that rill initiation time decreased with an increase in slope gradient. Moreover, differences in rill initiation time between millet, maize, and soybean crops, and bare surface on $2^{\circ}$ slopes were $5.15,1.01$, and $1.92 \mathrm{~min}$, respectively, under a unit discharge rate of $0.1 \mathrm{~L} \mathrm{~m}^{-1} \mathrm{~s}^{-1}$, which decreased to $2.33,0.89$, and $1.75 \mathrm{~min}$, respectively, on the basis of the $12^{\circ}$ slope, indicating that the capacity of crops to hinder rill generation decreased with an increase in slope gradient, and unit discharge rate had a similar effect on the basis of a similar analysis.

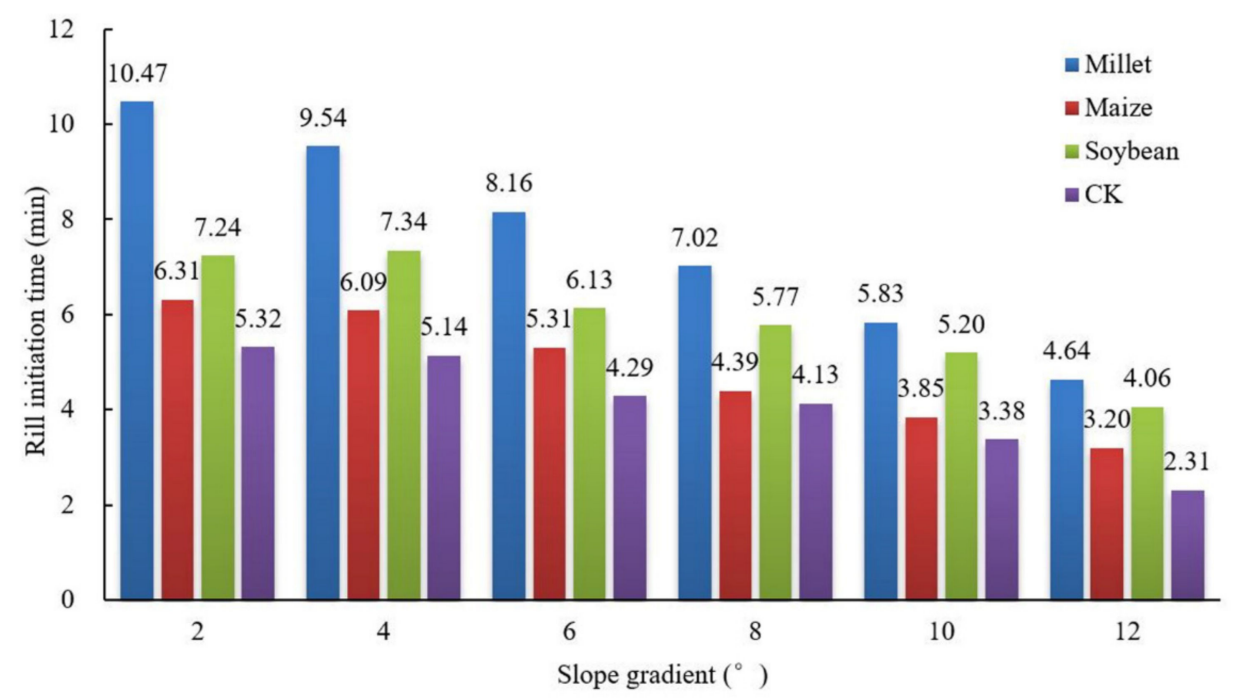

Figure 4. The rill initiation time under different crops cover versus slope gradient with a unit discharge of $0.1 \mathrm{~L} \mathrm{~m}^{-1} \mathrm{~s}^{-1}$.

Overall, the flow scouring effect was relatively low under low slope gradient and low unit discharge rate conditions. Conversely, under high slope gradient and high unit discharge rates, the scouring effect intensified, resulting in a reduction of rill initiation time and a decrease in the influence of crop cover on rill initiation time.

\subsection{Correlations between Soil Detachment Rate, Slope Gradient, and Unit Discharge Rate}

Slope gradient and unit discharge rate are two key variables that influence soil detachment. Table 5 lists the detachment rates under different crop covers with different slope gradients and unit discharge rates. Soil detachment rates among different crop covers were significantly different $(p<0.05)$ under different slope gradients and unit discharge rates. Figure 5 illustrates how the two parameters influence soil detachment rate under different crop covers.

Generally, soil detachment rate increased with the rising of both slope gradient and unit discharge rate on all surfaces. For instance, the mean soil detachment rates under millet, maize, and soybean cover, and bare surface increased by $2.511,5.711,2.821$, and $7.962 \mathrm{~g} \mathrm{~m}^{-2} \mathrm{~s}^{-1}$, respectively, as slope gradient increased from $2^{\circ}$ to $12^{\circ}$, and increased by $1.862,2.879,1.852$, and $6.650 \mathrm{~g} \mathrm{~m}^{-2} \mathrm{~s}^{-1}$, respectively, as unit discharge rate increased from $0.1 \mathrm{~L}$ to $0.3 \mathrm{~L} \mathrm{~m}^{-1} \mathrm{~s}^{-1}$. The increasing effects of slope gradient and unit discharge rate on soil detachment rate were in the order of $\mathrm{CK}>$ maize $>$ soybean $>$ millet, implying that crops could attenuate the increasing soil erosion trends significantly with increases in slope gradient and unit discharge when compared with the bare surface. The weakening effect was the greatest under maize cover, and the least under millet cover. 
Table 5. The detachment rates under different crops with different slope gradient and unit discharge.

\begin{tabular}{|c|c|c|c|c|c|}
\hline \multirow{2}{*}{ Unit Discharge $\left(\mathrm{L} \mathrm{m}^{-1} \mathrm{~s}^{-1}\right)$} & \multirow{2}{*}{ Slope Gradient $\left({ }^{\circ}\right)$} & \multicolumn{4}{|c|}{ Soil Detachment Rate $\left(\mathrm{g} \mathrm{m}^{-2} \mathrm{~s}^{-1}\right)$} \\
\hline & & CK & Millet & Maize & Soybean \\
\hline \multirow{6}{*}{0.1} & 2 & 0.011 & 0.001 & 0.026 & 0.059 \\
\hline & 4 & 0.023 & 0.004 & 0.576 & 0.421 \\
\hline & 6 & 0.041 & 0.359 & 0.429 & 0.763 \\
\hline & 8 & 0.054 & 1.180 & 0.990 & 3.648 \\
\hline & 10 & 1.233 & 1.783 & 1.927 & 1.855 \\
\hline & 12 & 1.755 & 1.465 & 2.641 & 1.458 \\
\hline \multirow{6}{*}{0.15} & 2 & 0.052 & 0.002 & 0.024 & 0.098 \\
\hline & 4 & 0.082 & 0.169 & 0.654 & 0.780 \\
\hline & 6 & 0.802 & 0.926 & 1.239 & 0.664 \\
\hline & 8 & 1.496 & 1.606 & 1.412 & 2.774 \\
\hline & 10 & 1.499 & 2.164 & 3.801 & 0.998 \\
\hline & 12 & 4.403 & 2.035 & 4.620 & 2.237 \\
\hline \multirow{6}{*}{0.2} & 2 & 0.088 & 0.065 & 0.195 & 0.374 \\
\hline & 4 & 0.109 & 0.626 & 1.018 & 0.771 \\
\hline & 6 & 1.722 & 0.968 & 2.737 & 2.196 \\
\hline & 8 & 3.767 & 3.528 & 1.639 & 4.127 \\
\hline & 10 & 4.906 & 3.100 & 2.980 & 2.670 \\
\hline & 12 & 7.446 & 2.877 & 5.820 & 2.911 \\
\hline \multirow{6}{*}{0.25} & 2 & 0.231 & 0.136 & 0.134 & 0.445 \\
\hline & 4 & 0.178 & 0.955 & 2.380 & 1.447 \\
\hline & 6 & 1.967 & 2.483 & 3.249 & 1.607 \\
\hline & 8 & 4.854 & 3.861 & 2.578 & 2.185 \\
\hline & 10 & 6.655 & 3.908 & 4.114 & 4.083 \\
\hline & 12 & 11.044 & 3.280 & 5.891 & 3.887 \\
\hline \multirow{6}{*}{0.3} & 2 & 1.076 & 0.151 & 0.439 & 0.685 \\
\hline & 4 & 2.510 & 1.450 & 2.259 & 1.641 \\
\hline & 6 & 5.168 & 2.867 & 3.750 & 3.468 \\
\hline & 8 & 7.813 & 4.214 & 3.978 & 3.835 \\
\hline & 10 & 9.835 & 4.033 & 6.035 & 4.413 \\
\hline & 12 & 16.620 & 3.254 & 7.403 & 5.274 \\
\hline
\end{tabular}

We carried out multiple regressions to assess how slope gradient $(S)$ and unit discharge $(q)$ influence soil detachment rate $(D r)$ with different crop covers. The regression equations are as follows:

$$
\begin{array}{cc}
\text { Millet : } D r=70.456 S^{0.966} q^{0.995} & R^{2}=0.802 \\
\text { Maize : } D r=198.497 S^{1.350} q^{0.982} & R^{2}=0.906 \\
\text { Soybean : } D r=69.989 S^{0.946} q^{0.944} & R^{2}=0.753 \\
\text { CK : } D r=4827.029 S^{2.024} q^{2.106} & R^{2}=0.976
\end{array}
$$

The regression equations indicated that detachment rate was positively correlated with both slope gradient and unit discharge rate on all surfaces, including under crop cover and on bare surfaces, with the $D r-S$ and $q$ relations being described as power functions. The coefficients of determination $\left(R^{2}\right)$ of all equations were high, indicating that soil detachment rate can be well predicted by a power function of slope gradient and unit discharge rate. In addition, the regression coefficients of slope gradient and unit discharge rate were quite close, and were 0.966 and 0.995 for millet, 1.350 and 0.982 for maize, and 0.946 and 0.944 for soybean, respectively, on slopes with millet, maize, and soybean, which indicated that both slope gradient and unit discharge rate have important effects on soil detachment rate in cropland, and the extents of the impacts were essentially similar. In addition, the regression coefficients of slope gradient and unit discharge were close to 1 under different 
crop covers, indicating that the effect of the change in slope and unit discharge is nearly linear in cropland.
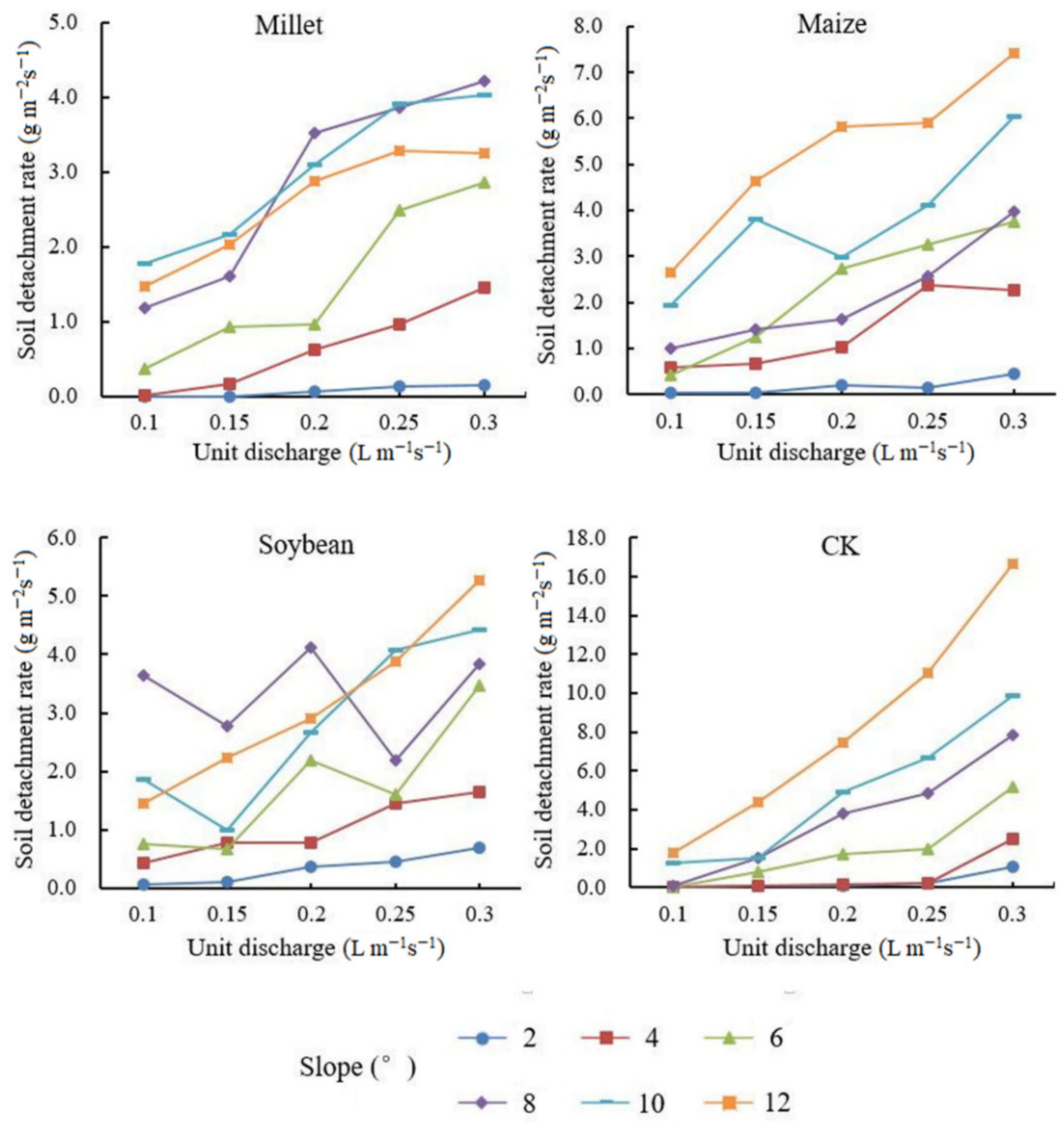

Figure 5. Soil detachment rate versus slope gradient and unit discharge rate under different crops.

In contrast, the regression coefficients of slope gradient and unit discharge rate on the bare surfaces were 2.024 and 2.106, respectively, which were nonlinear and significantly larger than those on cropped surfaces, indicating that the effects of the change in slope and unit discharge were related to root system but not crop density, and crops can weaken the increasing detachment rate trend with increases in slope gradient and unit discharge rate when compared with a bare surface. The results are consistent with our previous conclusion.

\subsection{Soil Detachment Rate with Different Crop Covers}

Across the four treatments, average soil detachment rate was the highest under CK $\left(3.248 \mathrm{~g} \mathrm{~m}^{-2} \mathrm{~s}^{-1}\right)$, followed by under maize $\left(2.498 \mathrm{~g} \mathrm{~m}^{-2} \mathrm{~s}^{-1}\right)$ and soybean $\left(2.059 \mathrm{~g} \mathrm{~m}^{-2} \mathrm{~s}^{-1}\right)$, and the least under millet cover $\left(1.782 \mathrm{~g} \mathrm{~m}^{-2} \mathrm{~s}^{-1}\right)$ (Table 5). Soil detachment rates in crops on slopes were lower than that on the bare surface, with significant differences $(p<0.05)$. The results are consistent with the findings of many previous studies [41-43]. Moreover, soil anti-erodibility under various crop covers varied in the order of millet $>$ soybean $>$ maize. The results of the present analysis are based on a crop system, while the antiscourability based on a single plant could present different results. According to the present experimental design, the planting densities of millet, maize, and soybean were 31.7, 3.7, and 11.0 individuals per square meter, respectively, with soil erosion rates in the order of maize $\left(0.675 \mathrm{~g} \mathrm{~m}^{-2} \mathrm{~s}^{-1}\right)>$ soybean $\left(0.187 \mathrm{~g} \mathrm{~m}^{-2} \mathrm{~s}^{-1}\right)>\operatorname{millet}\left(0.056 \mathrm{~g} \mathrm{~m}^{-2} \mathrm{~s}^{-1}\right)$, as the difference of planting density of three crops was excluded. Consequently, not only the 
soil reinforcement capability of a single crop but also crop planting density influenced the erosion characteristics in croplands.

Root systems regulate soil erosion when rills are formed and when rill head gradually "cut down" as gully erosion intensifies. Both millet and maize have fibrous root systems, whereas soybean has a tap root system. Therefore, the effects of differences in root characteristics among different crops should be taken into account.

The main crop root system characteristics are listed in Table 6. According to the root scanning results, average root diameter in the three crops was in the order of soybean $(0.97 \mathrm{~mm})>$ maize $(0.85 \mathrm{~mm})>$ millet $(0.63 \mathrm{~mm})$. In addition, RD, RLD, and RSAD of millet were the highest, followed by those of soybean and maize. Conversely, soybean had the largest RVD, and that of millet was slightly lower than that of soybean, with maize having the lowest RVD. According to the results of one-way ANOVA, root diameter and RVD had non-significant effects on soil detachment rate, whereas RD, RLD, and RSAD had significant effects $(p<0.05)$ on soil detachment rate. However, some researchers have demonstrated that anti-scourability varies under different root diameter ranges [44,45]. Consequently, to further study how root characteristics influence soil detachment rate, we divided roots into diameter ranges at five intervals $(0-0.5,0.5-1,1-2,2-5$, and $>5 \mathrm{~mm})$, and the root scanning data were reclassified and analyzed (Figure 6). According to the results, there were still significant differences in root characteristics across different crops $(p>0.05)$ in each of the root diameter intervals.

Table 6. Mean values and standard deviation of root parameters of tested crops.

\begin{tabular}{cccc}
\hline Root Parameter & Millet & Maize & Soybean \\
\hline Average diameter $(\mathrm{mm})$ & $0.63 \pm 0.07$ & $0.85 \pm 0.04$ & $0.97 \pm 0.16$ \\
Root weight density $\left(\mathrm{kg} \mathrm{m}^{-3}\right)$ & $0.81 \pm 0.12$ & $0.42 \pm 0.06$ & $0.69 \pm 0.09$ \\
Root length density $\left(\mathrm{m} \mathrm{m}^{-3}\right)$ & $753.44 \pm 103.37$ & $256.92 \pm 87.34$ & $360.08 \pm 123.23$ \\
Root surface area density $\left(\mathrm{m}^{2} \mathrm{~m}^{-3}\right)$ & $1.41 \pm 0.24$ & $0.67 \pm 0.08$ & $1.13 \pm 0.10$ \\
Root volume density $\left(\mathrm{cm}^{3} \mathrm{~m}^{-3}\right)$ & $236.55 \pm 38.16$ & $137.54 \pm 18.95$ & $247.17 \pm 30.43$ \\
\hline Note: As an example $0.63 \pm 0.07$ refer to the mean with standard deviations; the same is the case in other cells
\end{tabular}

The root length densities of millet, maize, and soybean were the maximum in the $0-0.5 \mathrm{~mm}$ root diameter range, accounting for $65.4 \%, 61.9 \%$, and $62.3 \%$ of the total root lengths, respectively. In addition, root length density was inversely proportional to root diameter in all three crops. Most crop roots were fine roots, with a root diameter of $0-0.5 \mathrm{~mm}$. RSAD first increased and then decreased with an increase in crop root diameter. Specifically, millet RSAD was the largest $\left(0.44 \mathrm{~m}^{2} \mathrm{~m}^{-3}\right)$ in the $0.5-1 \mathrm{~mm}$ root diameter range, accounting for $33.6 \%$ of the total root surface area, and the smallest in the $>5 \mathrm{~mm}$ root diameter range, accounting for $1.1 \%$ of the total root surface area. Soybean RSAD trends were largely consistent with those of millet, with the maximum $\left(0.29 \mathrm{~m}^{2} \mathrm{~m}^{-3} ; 32.2 \%\right)$ in the $0.5-1 \mathrm{~mm}$ root diameter range, and the minimum $\left(0.09 \mathrm{~m}^{2} \mathrm{~m}^{-3} ; 9.8 \%\right)$ in the range $>5 \mathrm{~mm}$ root diameter range. In the case of maize, RSAD was the largest $\left(0.21 \mathrm{~m}^{2} \mathrm{~m}^{-3} ; 34.3 \%\right)$ in the $2-5 \mathrm{~mm}$ root diameter range; nevertheless, the RSAD was not significantly different from those in other diameter intervals. In addition, RVD in both millet and maize increased first and then decreased with an increase in root diameter. RVD of millet in 2-5 $\mathrm{mm}$ root diameter range was the largest $\left(96.04 \mathrm{~cm}^{3} \mathrm{~m}^{-3}\right)$, accounting for $41.5 \%$ of the total volume, and the smallest in the $>5 \mathrm{~mm}$ root diameter range, accounting for $4.4 \%$. The largest RVD in maize $\left(63.78 \mathrm{~cm}^{3} \mathrm{~m}^{-3} ; 45.1 \%\right)$ was observed in the $2-5 \mathrm{~mm}$ root diameter range, and the smallest $\left(8.61 \mathrm{~cm}^{3} \mathrm{~m}^{-3} ; 1.7 \%\right)$ was observed in the $0-0.5 \mathrm{~mm}$ root diameter range. Unlike millet and maize RVDs, soybean RVD increased exponentially with an increase in root diameter, and the maximum in the $>5 \mathrm{~mm}$ range was $80.94 \mathrm{~cm}^{3} \mathrm{~m}^{-3}(32.6 \%)$, whereas the minimum in the $0-0.5 \mathrm{~mm}$ range was $17.22 \mathrm{~cm}^{3} \mathrm{~m}^{-3}(3.5 \%)$. 

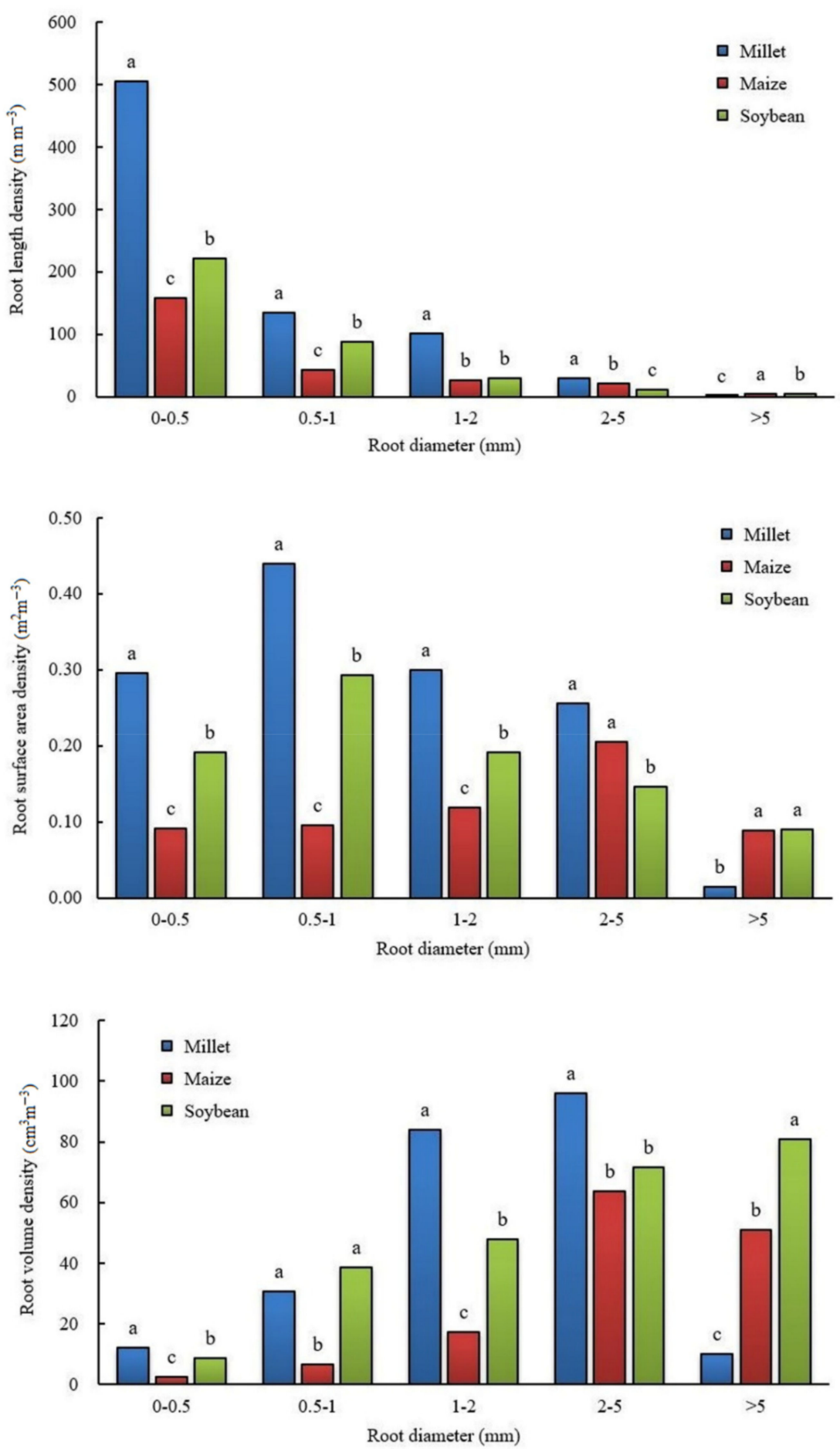

Figure 6. The root parameters of different ranges of root diameter for different crops. Note: For each range of root diameter, significant differences of root parameters between different crops $(p<0.05)$ are denoted by different letters.

To investigate the potential influence of root characteristics under different diameter ranges on soil detachment rate, we conducted a correlation analysis between detachment rate and root parameter of tested crops using one-way ANOVA (Table 7). According to the results, the correlations between all root parameters and soil detachment rate were negative, indicating that RLD, RSAD, and RVD were negatively correlated with soil detachment rate. Moreover, in the $0-0.5 \mathrm{~mm}$ and $0.5-1 \mathrm{~mm}$ root diameter ranges, the correlations between root parameters and soil detachment rate were highly significant $(p<0.01)$. In addition, 
the correlations in the $0-0.5 \mathrm{~mm}$ root diameter range were more significant than those in the $0.5-1 \mathrm{~mm}$ root diameter range. In the $1-2 \mathrm{~mm}$ root diameter range, the correlations between soil detachment rate and RLD and RSAD were significant $(p<0.05)$, although the correlation with RVD was not significant. In the $2-5 \mathrm{~mm}$ and $>5 \mathrm{~mm}$ root diameter ranges, the correlations between soil erosion rate and RLD, RSAD, and RVD were not significant.

Table 7. Correlation analysis between detachment rate and root parameters with different ranges of root diameters.

\begin{tabular}{ccccc}
\hline \multirow{2}{*}{ Root Parameter } & Range of Root Diameter & \multicolumn{3}{c}{ Crops } \\
\cline { 2 - 5 } & & Millet & Maize & Soybean \\
\hline \multirow{3}{*}{$\begin{array}{c}\text { Root length } \\
\text { density }\end{array}$} & $0-0.5 \mathrm{~mm}$ & $-0.883^{* *}$ & $-0.867^{* *}$ & $-0.904^{* *}$ \\
& $0.5-1 \mathrm{~mm}$ & $-0.829^{* *}$ & $-0.795^{* *}$ & $-0.771^{* *}$ \\
& $1-2 \mathrm{~mm}$ & $-0.652^{*}$ & $-0.590^{*}$ & $-0.583^{*}$ \\
& $2-5 \mathrm{~mm}$ & -0.416 & -0.388 & -0.421 \\
Root surface & $>5 \mathrm{~mm}$ & -0.217 & -0.209 & -0.195 \\
area density & $0-0.5 \mathrm{~mm}$ & $-0.879^{* *}$ & $-0.902^{* *}$ & $--0.897^{* *}$ \\
& $0.5-1 \mathrm{~mm}$ & $-0.833^{* *}$ & $-0.818^{* *}$ & $-0.791^{* *}$ \\
& $1-2 \mathrm{~mm}$ & $-0.644^{*}$ & $-0.680^{*}$ & $-0.635^{*}$ \\
Root volume & $2-5 \mathrm{~mm}$ & -0.402 & -0.365 & $-0.344^{*}$ \\
density & $>5 \mathrm{~mm}$ & -0.171 & -0.249 & -0.266 \\
& $0-0.5 \mathrm{~mm}$ & $-0.837^{* *}$ & $-0.815^{* *}$ & $-0.886^{* *}$ \\
& $0.5-1 \mathrm{~mm}$ & $-0.722^{*}$ & $-0.756^{* *}$ & $-0.779^{* *}$ \\
& $1-2 \mathrm{~mm}$ & -0.538 & -0.464 & -0.510 \\
& $2-5 \mathrm{~mm}$ & -0.231 & -0.304 & -0.319 \\
& $>5 \mathrm{~mm}$ & -0.162 & -0.223 & -0.215
\end{tabular}

Note: ${ }^{*}$ and ${ }^{* *}$ indicate significant correlation $(p<0.05)$ and extremely significant correlation $(p<0.01)$, respectively. The same below.

Data analysis showed that the correlations between crop root parameters and soil erosion rate were highly significant in the $0-1 \mathrm{~mm}$ root diameter range $(p<0.01)$, and decreased gradually with an increase in root diameter, which indicates that crop roots in the $0-1 \mathrm{~mm}$ diameter range could significantly influence soil erosion in cropped slopes, as well as improve cropland anti-erodibility capacity. Such a finding has also been reported by Wang [46]. Among the root parameters examined, soil detachment rate was more sensitive to RLD and RSAD than to RVD.

\section{Conclusions}

In the present study, rill initiation times on the slopes with crop covers were longer than that on the bare slope, in the order of millet $>$ soybean $>$ maize $>C K$, indicating that the crops had considerable soil consolidation effects. However, with increases in slope and unit discharge rate, the capacities of crops to hinder rill generation decreased. In addition, crops could significantly slow down increasing soil erosion trends on sloping farmland with increases in slope gradient and unit discharge rates. As the planting density in the present study was in the order of millet $>$ soybean $>$ maize, the sediment loss reduction capacity was also in the order of millet $>$ soybean $>$ maize. Conversely, when considering only single plants, we found that the sediment loss reduction capacity was in the order of maize $>$ soybean $>$ millet. The trends indicate that the erosion reduction effects of crops depend not only on crop species but also on crop planting density. Regression analysis results showed that soil detachment rate had positive power function relationships with slope gradient and unit discharge rate, and the regression coefficients of slope gradient and unit discharge rate in cropped slopes were lower than those in bare surfaces, indicating that the increases in soil detachment rate on cropped slopes are lower than that on the bare slope with increases in slope gradient and unit discharge rate. The results further confirm the anti-erodibility functions of the crop cover. 
Soil detachment rate was closely related to crop root characteristics. The average root diameter, RD, RLD, RSAIS, and RVD of crops were negatively correlated with the soil erosion rate. Among them, the correlations between RLD and RSAD and soil erosion rate were more significant, with roots in $0-1 \mathrm{~mm}$ diameter range having the greatest influence on soil erosion rate.

Author Contributions: Conceptualization, J.S. and P.L. (Pei Lu); methodology, J.S. and Y.C.; software, J.S. and N.Z.; validation, P.L. (Pei Lu); formal analysis, J.S. and N.Z.; investigation, J.S.; resources, P.L. (Pei Lu); data curation, J.S. and F.W.; writing—original draft preparation, J.S.; writing-review and editing, J.S. and F.W.; visualization, J.S.; supervision, P.L. (Peng Li); project administration, P.L. (Pei $\mathrm{Lu}$ ) and N.Z.; funding acquisition, P.L. (Pei Lu) and N.Z. All authors have read and agreed to the published version of the manuscript.

Funding: This research was jointly funded by the Technology Program for Ecological Protection and High Quality Development of The Yellow River Basin (grant. no. KJB2021XZ02) and National Natural Science Foundation of China (grant. no. 42167048).

Institutional Review Board Statement: Not applicable.

Informed Consent Statement: Not applicable.

Data Availability Statement: The data presented in this study are available on request from the corresponding author. The data are not publicly available due to the need for the follow-up studies.

Conflicts of Interest: The authors declare no conflict of interest.

\section{References}

1. The effect of land uses and rainfall regimes on runoff and soil erosion in the semi-arid loess hilly area, China. J. Hydrol. 2007, 335, 247-258. [CrossRef]

2. Keesstra, S.; Pereira, P.; Novara, A.; Brevik, E.C.; Azorin-Molina, C.; Parras-Alcántara, L.; Jordán, A.; Cerdà, A. Effects of soil management techniques on soil water erosion in apricot orchards. Sci. Total Environ. 2016, 551-552, 357-366. [CrossRef] [PubMed]

3. Zhang, X.-C.; Liu, W. Simulating potential response of hydrology, soil erosion, and crop productivity to climate change in Changwu tableland region on the Loess Plateau of China. Agric. For. Meteorol. 2005, 131, 127-142. [CrossRef]

4. Zhao, G.; Mu, X.; Wen, Z.; Wang, F.; Gao, P. Soil erosion, conservation, and eco-environment changes in the Loess Plateau of China. Land Degrad. Dev. 2013, 24, 499-510. [CrossRef]

5. $\quad$ Tang, K.L.; Zhang, Z.Z.; Kong, X.L. A Story of Soil Loss and Soil Degradation on the Loess Plateau in China; Springer: Dordrecht, The Netherlands, 1989. [CrossRef]

6. Montgomery, D.R. Soil erosion and agricultural sustainability. Proc. Natl. Acad. Sci. USA 2007, 104, 13268-13272. [CrossRef] [PubMed]

7. Moreno, H.R.; Quizembe, S.J.; Ibáñez, S.A. Coffee husk mulch on soil erosion and runoff: Experiences under rainfall simulation experiment. Solid Earth 2014, 5, 851-862. [CrossRef]

8. Borrelli, P.; Märker, M.; Schütt, B. Modelling Post-Tree-Harvesting Soil Erosion and Sediment Deposition Potential in the Turano River Basin (Italian Central Apennine). Land Degrad. Dev. 2015, 26, 356-366. [CrossRef]

9. Xie, Y.; Lin, H.; Ye, Y.; Ren, X. Changes in soil erosion in cropland in northeastern China over the past 300 years. CATENA 2019, 176, 410-418. [CrossRef]

10. Zhou, J.; Fu, B.; Gao, G.; Lü, Y.; Liu, Y.; Lü, N.; Wang, S. Effects of precipitation and restoration vegetation on soil erosion in a semi-arid environment in the Loess Plateau, China. CATENA 2016, 137, 1-11. [CrossRef]

11. Zhou, Z.C.; Gan, Z.T.; Shangguan, Z.P.; Dong, Z.B. China's Grain for Green Program has reduced soil erosion in the upper reaches of the Yangtze River and the middle reaches of the Yellow River. Int. J. Sust. Dev. World 2009, 16, 234-239. [CrossRef]

12. Wu, S.; Wu, P.; Feng, H.; Merkley, G.P. Effects of alfalfa coverage on runoff, erosion and hydraulic characteristics of overland flow on loess slope plots. Front. Environ. Sci. Eng. China 2011, 5, 76-83. [CrossRef]

13. Cerda, A. The influence of geomorphological position and vegetation cover on the erosional and hydrological processes on a Mediterranean hill slope. Hydrol. Process. 2015, 12, 661-671. [CrossRef]

14. Wainwright, J.; Parsons, A.; Abrahams, A.D. Plot-scale studies of vegetation, overland flow and erosion interactions: Case studies from Arizona and New Mexico. Hydrol. Process. 2000, 14, 2921-2943. [CrossRef]

15. Zhang, X.Y.; Zhou, Z.C.; Wang, N. Research progress of soil and water conservation functions of grass aboveground part. Soil Water Conserv. China 2015, 1, 47-50+69. (In Chinese) [CrossRef]

16. Olson, K.R.; Gennadiyev, A.N.; Jones, R.L. Erosion Patterns on cultivated and Reforested Hillslopes in Moscow Region, Russia. Soil Sci. Soc. Am. J. 2002, 66, 193-201. [CrossRef]

17. Holtham, D.A.; Matthews, G.P.; Scholefield, D.S. Measurement and simulation of void structure and hydraulic changes caused by root-induced soil structuring under white clover compared to ryegrass. Geoderma 2007, 142, 142-151. [CrossRef] 
18. Hu, W.; Shao, M.; Wang, Q.; Fan, J.; Horton, R. Temporal changes of soil hydraulic properties under different land uses. Geoderma 2009, 149, 355-366. [CrossRef]

19. Morgan, R.P.C.; Quinton, J.N.; Smith, R.E.; Govers, G.; Poesen, J.W.A.; Auerswald, K.; Chisci, G.; Torri, D.; Styczen, M.E The European Soil Erosion Model (EUROSEM): A dynamic approach for predicting sediment transport from fields and small catchments. Earth Surf. Proc. Land. 1998, 23, 527-544. [CrossRef]

20. Bochet, E.; Poesen, J.; Rubio, J. Influence of plant morphology on splash erosion in a Mediterranean matorral. Z. Geo Morphol. 2002, 46, 223-243. [CrossRef]

21. Sun, C.J.; Hou, H.X.; Chen, W.; Yang, W.; Zheng, Z.J. Effects of different plant measures on soil and water conservation in typical tableland zones on the Loess Plateau. J. Nat. Resour. 2019, 34, 1405-1416. (In Chinese) [CrossRef]

22. Zuazo, V.H.D.; Pleguezuelo, C.R.R. Soil-erosion and runoff prevention by plant covers. A review. Agron. Sustain. Dev. 2008, 28, 65-86. [CrossRef]

23. Didone, E.J.; Minella, J.P.G.; Evrard, O. Measuring and modelling soil erosion and sediment yields in a large cultivated catchment under no-till of Southern Brazil. Soil Tillage Res. 2017, 174, 24-33. [CrossRef]

24. Huang, J.; Wu, P.; Zhao, X. Effects of rainfall intensity, underlying surface and slope gradient on soil infiltration under simulated rainfall experiments. CATENA 2013, 104, 93-102. [CrossRef]

25. Huang, J.; Zhao, X.; Wu, P. Surface runoff volumes from vegetated slopes during simulated rainfall events. J. Soil Water Conserv. 2013, 68, 283-295. [CrossRef]

26. Wang, L.; Ma, B.; Wu, F. Effects of wheat stubble on runoff, infiltration, and erosion of farmland on the Loess Plateau, China, subjected to simulated rainfall. Solid Earth 2017, 8, 281-290. [CrossRef]

27. Udayakumara, E.P.N.; Shrestha, R.P.; Samarakoon, L.; Schmidt-Vogt, D. People's perception and socioeconomic determinants of soil erosion: A case study of Samanalawewa watershed, Sri Lanka. Int. J. Sediment Res. 2010, 25, 323-339. [CrossRef]

28. Chalise, D.; Kumar, L.; Kristiansen, P. Land Degradation by Soil Erosion in Nepal: A Review. Soil Syst. 2019, 3, 12. [CrossRef]

29. Ma, B.; Wu, F.Q.; Li, Z.B.; Wang, J. Interaction of Crop Cover and Slope Gradient on Runoff and Sediment Yield. J. Soil Water Conserv. 2013, 27, 33-38. (In Chinese)

30. Zhao, X.; Huang, J.; Wu, P.; Gao, X. The dynamic effects of pastures and crop on runoff and sediments reduction at loess slopes under simulated rainfall conditions. CATENA 2014, 119, 1-7. [CrossRef]

31. Carroll, C.; Halpin, M.; Burger, P.; Bell, K.; Sallaway, M.M.; Yule, D.F. The effect of crop type, crop rotation, and tillage practice on runoff and soil loss on a Vertisol in central Queensland. Aust. J. Soil Res. 1997, 35, 925-940. [CrossRef]

32. Basic, F.; Kisic, I.; Butorac, A.; Nestroy, O.; Mesic, M. Runoff and soil loss under different tillage methods on Stagnic Luvisols in central Croatia. Soil Tillage Res. 2001, 62, 145-151. [CrossRef]

33. Basic, F.; Kisic, I.; Mesic, M.; Nestroy, O.; Butorac, A. Tillage and crop management effects on soil erosion in central Croatia. Soil Tillage Res. 2004, 78, 197-206. [CrossRef]

34. Martens, D.A. Relationship Between Plant Phenolic Acids Released during Soil Mineralization and Aggregate Stabilization. Soil Sci. Soc. Am. J. 2002, 66, 1857-1867. [CrossRef]

35. Song, Y.Q. The Runoff and Sediment Regulation of Grass Covers in Loess Slopes. Master's Thesis, Northwest A\&F University, Yangling, China, 2016. (In Chinese).

36. Lu, P.; Xie, X.; Wang, L.; Wu, F. Effects of different spatial distributions of physical soil crusts on runoff and erosion on the Loess Plateau in China. Earth Surf. Process. Landf. 2017, 42, 2082-2089. [CrossRef]

37. Wang, L.; Dalabay, N.; Lu, P.; Wu, F. Effects of tillage practices and slope on runoff and erosion of soil from the Loess Plateau, China, subjected to simulated rainfall. Soil Tillage Res. 2017, 166, 147-156. [CrossRef]

38. Zhao, X.; Huang, J.; Gao, X.; Wu, P.; Wang, J. Runoff features of pasture and crop slopes at different rainfall intensities, antecedent moisture contents and gradients on the Chinese Loess Plateau: A solution of rainfall simulation experiments. CATENA 2014, 119, 90-96. [CrossRef]

39. Lin, Q.; Xu, Q.; Wu, F.; Li, T. Effects of wheat in regulating runoff and sediment on different slope gradients and under different rainfall intensities. CATENA 2019, 183, 104196. [CrossRef]

40. Wang, M.B.; Zhang, R. Issues in using the WinRHIZO system to determine physical characteristics of plant fine roots. Acta Ecol. Sin. 2009, 29, 136-138. [CrossRef]

41. De Baets, S.; Poesen, J.; Meersmans, J.; Serlet, L. Cover crops and their erosion-reducing effects during concentrated flow erosion. CATENA 2011, 85, 237-244. [CrossRef]

42. Zhao, L.; Liang, X.; Wu, F. Soil surface roughness change and its effect on runoff and erosion on the Loess Plateau of China. J. Arid Land 2014, 6, 400-409. [CrossRef]

43. Guo, Q.; Hao, Y.; Liu, B. Rates of soil erosion in China: A study based on runoff plot data. CATENA 2015, 124, 68-76. [CrossRef]

44. Xiong, Y.M.; Xia, H.P.; Li, Z.A.; Cai, X.A. Effects and mechanisms of plant roots on slope reinforcement and soil erosion resistance: A research review. Chin. J. Appl. Ecol. 2007, 18, 895-904. (In Chinese) [CrossRef]

45. Liu, G.B. Study on soil anti-scourability and its mechanism of grassland on loess plateau. J. Soil Water Conserv. 1998, 4, 93-96. (In Chinese)

46. Wang, J.L.; Wu, F.Q. Soil erosion resistance of sloping farmland under soybean cultivation relative to growth stage. China Rural. Water Conserv. Hydropower 2016, 53, 1389-1398. (In Chinese) [CrossRef] 